\title{
Abstracts
}

\author{
Sandra Dieterich/Hartwig Hummel/Stefan Marschall \\ Spoiling the War Game? \\ European Parliaments and the 2003 Iraq War \\ ZIB, Vol. 16, No. 1, pp. 5-38
}

Democracies differ significantly from each other concerning their war restraint. Still this should not be taken as an easy refutation of the (monadic) democratic peace proposition that democracy is generally conducive to peace. For it could be the different democratic qualities of national security policy-making which explain the variance in democracies « war involvement. By operationalizing »democratic« security policy-making as »parliamentary control« of security policy we can hypothesize that countries with powerful parliaments in terms of security policy-making are more war averse than countries with weak parliamentary war powers - provided that public opinion is clearly opposed to war involvement. This hypothesis of "parliamentary peace $\ll$ is tested by examining the involvement of 25 European democracies in the 2003 Iraq war. We determine the degree of the respective parliamentary war powers and the extent of the involvement of these countries in the military intervention against Iraq and then correlate the two variables. The findings basically support the hypothesis of »parliamentary peace« but also reveal that further research has to be done.

\section{Lisbeth Zimmermann}

\section{Where does (Democratic) Peace Start?}

Regime changes, instability, integration and their influence on the conflict between Ecuador and Peru

ZIB, Vol. 16, No. 1, pp. 39-73

The thesis of a Democratic Peace is largely considered a consensus in Political Science. When and why peaceful behaviour between democracies starts and how the conflict behaviour of a state dyad changes during different regime constellations, needs further investigation. The dyad Ecuador-Peru is an enduring rivalry characterized by a long standing border conflict. On the basis of its different regime constellations the dyad s conflict behaviour will be analyzed. A deficit of the classical theories of Democratic Peace becomes apparent regarding the explanation of a start of peaceful interaction. But alternative approaches do not help form a comprehensive picture: Hasenclever (2002) states a connection of peaceful behaviour and inter-democratic integration after democratization. Mansfield «s and Snyder «s work on democratization and inter-state conflict (1995 a, 2004), in contrast, suggests anticipating 
peaceful behaviour in phases of institutional stability. An advancement of theory could be the investigation of changes of perceptions in both the region and the dyad.

\section{Ingo Rohlfing}

\section{Bilateralism and Multilateralism in International Relations}

A Political-Economy Approach and the Case of International Trade ZIB, Vol. 16, No. 1, pp. 75-101

Bilateralism and multilateralism represent one of the key dimensions in international cooperation. However, there are only few studies examining the determinants of the choice between these two forms of cooperation. In this paper, I propose a politicaleconomy approach that explains the decision between bilateralism and multilateralism. The choice between the two forms of cooperation is marked by conflicting incentives. On the one hand, states seek bilateralism in order to achieve their distributional goals through specific reciprocity and fine-tune concession-making. On the other hand, bilateral cooperation creates externalities and high transaction costs that set an incentive for multilateralism, which, however, makes it problematic to pursue distributional goals. The decision between the two forms of cooperation depends on whether concerns about distribution prevail over concerns about the externalities or vice versa. A plausibility probe of two cases of international trade cooperation provides empirical support for this account.

\section{Hans-Jürgen Bieling}

\section{When the Snowball Starts Rolling}

Reflections on the Dynamics and the Character of the Subprime Crisis ZIB, Vol. 16, No. 1, pp. 107-121

The »suprime crisis « can be taken as evidence of the financial Keynesian thesis of an inherent instability of finance-mediated economic relations. In this sense, the course of the crisis corresponds to a multi-stage interpretation model which was developed by Charles Kindleberger with reference to the financial Keynesian approach of Hyman Minsky. In order to map the particular quality of the »subprime crisis« as the starting point of the crisis of the global financial system as a whole, it is, however, necessary to transcend the outlined multi-stage model of financial crises. Accordingly, in the second part of the article it is shown that the mode of operation of the so-called Dollar Wall Street Regime (DWSR) which promoted speculative and financial bubbles until recently is now, as consequence of the global financial crisis, under consideration itself. 
Andreas Nölke

Financial Crisis, Financialization and Comparative Capitalism

ZIB, Vol. 16, No. 1, pp. 123-139

The article explains the emergence and the consequences of the crisis by drawing on established theories of International Political Economy. It uses the »Financialization«-concept for an inter-temporal study and the »Comparative Capitalism« research program for an inter-national perspective. In an inter-temporal perspective, the contribution demonstrates that both the emergence and the extent of the crisis are impossible to understand without taking due notice of the fundamental processes of company and household financialization during the last three decades. Financialization is defined as a process whereby the share of the financial sector within profits and household income permanently increases, to the detriment of the share of the production sector. In an inter-national perspective, the article explains the more severe repercussions of the crisis within Anglo-Saxon economies by pointing towards the more important role of financial markets within these liberal economies, whereas the classical »Hausbanken« within coordinated economies have been more moderately affected.

\section{Brigitte Young}

\section{From State-centred to Privatized Keynesianism}

The Global Macroeconomic Context of the Financial Crisis and Private Indebtedness ZIB, Vol. 16, No. 1, pp. 141-159

The paper analyzes the financial/credit crisis and the financialization of the global economic growth model in the context of a shift to a macroeconomic growth regime of privatized Keynesianism. The concept of privatized Keynesianism refers to a change from a state-centred socio-economic growth model to a consumer financed and private debt regime which institutionally developed in the US in the $1990 \mathrm{~s}$. In the centre of the global reconfiguration of creditors and debtors was the US-American housing market. The mortgage market functioned as a form of residential capitalism, which was financed through global liquidity surpluses. In turn these international capital flows were the driving force for the dynamism supporting the American highly indebted consumption economy, and acted as a locomotive for the ensuing global economic boom. Home ownership turned into a functional equivalent of the previously state-centred Keynesian demand management guaranteeing aggregate demand despite wage stagnation and cuts in welfare programmes. 
Oliver Kessler

\section{The Subprime-Crisis and the Question of Financial Stability}

ZIB, Vol. 16, No. 1, pp. 161-175

The Subprime-Crisis has led to a discursive change. With the collapse of the American mortgage market, monetarist ideas were invalidated and replaced by revived Keynesianism. The current attempt to revive the economy by stimulus packages and state interventions, including the quasi-nationalisation of vulnerable banks signals this discursive change. In this contribution I nevertheless argue that the subprime crisis does not only require a better understanding of hedge funds, rating agencies and the employment of derivates and complex financial instruments, but that it also raises more conceptual issues concerning the notion of systemic risk. Presently, the current debate on how to reform global finance is based on a concept of stability, which perpetuates central monetarist ideas that foreclose further inquiries as to how the discursive change can translate into a renegotiation over the current institutional order. For an institutional alternative to the current monetarist-based system, it is necessary that there is a different concept of stability that is open to the complex and evolutionary conditions of finance; and the political and social preconditions of financial practices. 